\title{
BEZBEDNOST TURISTA I POSETILACA NA MANIFESTACIJAMA U URBANIM SREDINAMA
}

\author{
Nevena Ćurčić ${ }^{1}$,̌eljko Bjeljac ${ }^{2}$, \\ $\mathrm{UDK}=351.758-057.68(1-21)$ \\ Aleksandra Terzić ${ }^{3}$ \\ https://doi.org/10.18485/fb_ubur.2018.1.ch22 \\ ${ }^{1}$ Prirodno-matematički fakultet, Univerzitet u Novom Sadu, \\ nevena.curcic@dgt.uns.ac.rs \\ ${ }^{2}$ Geografski institut ,Jovan Cvijić“ SANU, Beograd, z.bjeljac@gi.sanu.ac.rs \\ ${ }^{3}$ Geografski institut ,Jovan Cvijić“ SANU, Beograd, a.terzic@gi.sanu.ac.rs
}

\section{Sažetak}

Turizam je postao globalni fenomen i važan izvor prihoda za mnoge zemlje i regije. Industrija događaja (manifestacija) postala je jedan od glavnih turističkih sektora i ostvarila značajan ekonomski doprinos turističkoj industriji. Sektor putovanja i turizma generisao je 7,6 triliona US \$ (10,2\% globalnog BDP) i 292 miliona radnih mesta u 2016. godini, što je jednako 1 od 10 mesta u globalnoj ekonomiji. Ovaj sektor ostvaruje 6,6\% ukupnog svetskog izvoza i skoro $30 \%$ ukupnog svetskog izvoza usluga. U budućnosti se očekuje njegov dalji rast, tako da bi u 2027. godini doprineo razvoju 380 miliona radnih mesta i daljem razvoju svetske ekonomije.

Atraktivni elementi su važni pokretači na putovanjima i na delu su kako u prirodnim tako i u urbanim sredinama. Turističke manifestacije predstavljaju važan povoljan činilac u privlačenju turista i sastavni su deo turističkog potencijala. U ponudi turističkih destinacija sve je više posebnih manifestacija, čije je osmišljavanje i izvođenje uslovljeno strateškim razlozima, pre svega ekonomske prirode. Uloga manifestacija u turističkoj poželjnosti destinacije značajna je i zbog njihovih turističkih, društvenih i kulturnih funkcija, kao i uloge u lokalnom i regionalnom razvoju.

Smatra se da se pozitivni učinci manifestacija ispoljavaju kroz: dodatno zapošljavanje lokalnog stanovništva, izgradnju i adaptaciju objekata, povećanje prihoda mesta domaćina, jačanje konkurentnosti i podizanje kvaliteta ponude, povećanje publiciteta i izgradnju imidža mesta/manifestacije i drugo.

U Srbiji manifestacioni turizam, koji je Strategijom razvoja turizma do 2015. godine istaknut kao prosperitetna vrsta turizma, na značaju dobija tek početkom sadašnjeg veka. Od tada su manifestacije istaknute kao mogući nosioci razvoja turizma pojedinih destinacija, odnosno pojedine su prepoznate kao potencijalni brend turizma Srbije (EXIT u Novom Sadu, Sabor trubača u Guči, Beer Fest u Beogradu i druge svetkovine). Istraživanjima je utvrđeno da se u Srbiji godišnje održi oko 2.000 manifestacija različitog karaktera i ranga. Osim popularnosti na domaćem tržištu, neki od događaja imaju potencijal i na međunarodnom tržištu, gde su već do sada stekli određen stepen popularnosti. 
Masovna okupljanja na otvorenom ili u salama, opuštena atmosfera, želja i potreba za novim iskustvom i druženjem sastavni su činioci doživljaja na manifestacijama. Upravo velika koncentracija ljudi na jednome mestu, kao i smanjen nivo opreznosti samih posetilaca na manifestacijama mogu biti meta terorističkih napada. Takođe, posetioci manifestacija su izloženi delovanju i nekih drugih negativnih pojava: džeparenja, krađe, zaraze, prevare prilikom menjanja novca, ponuda psihoaktivnih supstanci i drugih nevolja. Svetski ekonomski forum je za potrebe veće bezbednosti putovanja izradio priručnike koji se bave postupcima tokom krize i posle krize, zasnovane na najboljim praksama i iskustvima destinacija koje su se sretale sa pojedinim krizama (politički prevrati, terorizam, pandemije, katastrofe u okruženju). Cilj rada je da ukaže koliko su turističke manifestacije bile izložene pojavama koje ugrožavaju bezbednost i sigurnost posetilaca generalno. Istraživanje se bavi i prisustvom ugrožavajućih elemenata na turističkim manifestacijama u Srbiji. Autori su koristili metodologiju primenjivu u društvenim naukama.

U istraživanju bezbednosti na domaćim manifestacijama korišćen je anketni upitnik koji je primenjen na festivalu Green Love u Novom Sadu među posetiocima ovog zbivanja. Uzorak je obuhvatio 120 ispitanika, pretežno mlađih od 29 godina. Zadatak istraživanja je bio da utvrdi na koji način mladi posetioci percipiraju bezbednost manifestacije i koje su to mere koje su ocenili kao dobre, a koje kao slabe. Većina ispitanika smatra da se nisu osećali ugroženo na festivalu ni na koji način (72\%). Takođe, $82 \%$ ispitanika nisu prisustvovali nasilju na festivalu. U slučaju potrebe pružanja pomoći nekoj osobi većina bi prišla da pomogne. Piće koje se prodaje ocenjeno je kao potpuno bezbedno. Elementi koji su slabije ocenjeni odnose se na potrebu većeg broja lica koja vrše obezbeđenje u sali, ispred sale bi trebao da bude veći broj medicinskih radnika, kao i veći broj pripadnika policije. Takođe, za bolje tehničko funkcionisanje festivala ispitanici smatraju da bi trebalo obezbediti veći broj ulaza u salu, bolju ventilaciju u toku festivala, kao i veći broj protivpožarnih aparata u sali.

Cilj rada je da ukaže koliko su turističke manifestacije izložene pojavama koje ugrožavaju bezbednost i sigurnost posetilaca generalno i koja su neka od rešenja koja se u svetu preduzimaju radi povećanja bezbednosti. Istraživanje se bavi i prisustvom elemenata koji narušavaju bezbednost na festivalu Green Love u Novom Sadu, a na osnovu percepcije samih posetilaca festivala. Zadatak istraživanja je bio da utvrdi na koji način mladi posetioci percipiraju bezbednost manifestacije i koje su mere ocenili kao dobre, a koje kao loše. Autori su koristili metodologiju primenjivu u društvenim naukama (anketni upitnik).

Rezultati istraživanja mogu pomoći organizatorima manifestacije da unaprede bezbednost kako bi se posetioci osećali još više sigurno. Proaktivan pristup bezbednosti na festivalu omogućiće veće zadovoljstvo posetilaca, bržu izgradnju brenda i dugoročan kontinuitet održavanja same manifestacije. Generalno, rezultati pokazuju da bezbednost turistâ predstavlja vodeći faktor konkurentnosti kako manifestacije tako i same turističke destinacije.

Ključne reči: bezbednost turista, manifestacije, konkurentnost destinacije, urbane sredine 


\section{Uvod}

Turizam je postao globalni fenomen i važan izvor prihoda za mnoge zemlje i regije. Sa porastom broja putovanja i boljim transportnim konekcijama širom sveta ostvareni su zapaženi socio-ekonomski efekti u međunarodnim putovanjima na globalnom nivou. Stoga ne čudi što mnogi autori ističu turizam kao važan izvor prihoda i pokretača nacionalne ekonomije (UNWTO, 2016; FaladeObalade, Dubey, 2014; Bhatia, 2007).

Sektor putovanja i turizma generisao je 7,6 triliona US\$ (10,2\% globalnog BDP) i 292 miliona radnih mesta u 2016. godini, što predstavlja 1 od 10 radnih mesta u globalnoj ekonomiji. Ovaj sektor ostvaruje 6,6\% ukupnog svetskog izvoza i gotovo 30\% ukupnog svetskog izvoza usluga. U budućnosti se očekuje njegov dalji rast, tako da bi u 2027. godini doprineo otvaranju 380 miliona radnih mesta i daljem razvoju svetske ekonomije (World Travel \& Tourism Council, 2017).

Industrija događaja (manifestacija) postala je jedan od glavnih turističkih sektora i ostvarila značajan ekonomski doprinos turističkoj industriji (Goldblatt, $\mathrm{Hu}, 2005)$. Zapravo, manifestacije su snažan motivator u turizmu (Getz, 2008). Turističke manifestacije predstavljaju važan atraktivan element u privlačenju turista i sastavni su deo turističke ponude. Razvoj ovog oblika turizma posebnih interesa postao je i samostalni nosilac turističke ponude, što ima pozitivne uticaje u urbanim sredinama. U ponudi turističkih destinacija sve je više posebnih manifestacija, čije je osmišljavanje i izvođenje uslovljeno strateškim razlozima, pre svega ekonomske prirode. Uloga manifestacija u turističkoj ponudi destinacije značajna je i zbog njihovih turističkih, društvenih i kulturnih funkcija, kao i uloge u lokalnom i regionalnom razvoju (Trošt et al., 2012).

$\mathrm{Ne}$ moraju sve manifestacije biti turistički orijentisane, odnosno turizam nije jedini partner ili pokretač manifestacija. Manifestacije imaju i druge važne uloge, koje se kreću od izgradnje zajednice do urbane obnove, od kulturnog razvoja do podsticanja nacionalnog identiteta (Getz, 2008). Ipak, manifestacije najčešće doprinose razvoju turizma u destinaciji i utiču na porast ukupne konkurentnosti same destinacije. Manifestacije prenose svoj imidž na destinaciju, što doprinosi uspehu u realizaciji prirodne i fizičke atrakcije gradova. Smatra se da se pvoljni učinci manifestacija ispoljavaju kroz: dodatno zapošljavanje lokalnog stanovništva, izgradnju i adaptaciju objekata, povećanje prihoda mesta domaćina, jačanje konkurentnosti i podizanje kvaliteta ponude, povećanje publiciteta i izgradnju imidža mesta/manifestacije i drugo.

Snažan podsticaj razvoju turizma daju velike manifestacije međunarodnog karaktera, pre svega sportske. Tako je na olimpijadi u Sidneju 2000. godine došlo do značajnog povećanja dolazaka inostranih i domaćih turista. Tokom igara je Sidnej ugostio 362.000 domaćih i 110.000 međunarodnih posetilaca. Pored toga, oko 4 milijarde ljudi gledalo je igre širom sveta. Svetsko prvenstvo u Rugbi-ju 2003. godine privuklo je 65.000 međunarodnih posetilaca u Australiju (URS Finance and Economics, 2004). Isto tako, osim velikih manifestacija i redovne sportske utakmice kod stranih turista mogu imati neposredan privlačan efekat. Omari Vilijams, 
programski menadžer sportskog menadžmenta na Univerzitetu u Derbiju, ukazuje na podatke o posetama Britaniji koji pokazuju da su fudbalski turisti koji su prisustvovali utakmicama engleskih liga doprineli ekonomiji u 2011. godini u iznosu od 706 miliona dolara, trošeći 785 funti po posetiocu, u poređenju sa 583 funte, koliko su trošili ne-sportski turisti. ,Zimski sportovi, kao što su fudbal i ragbi, izuzetno su atraktivno sredstvo za tur-operatore i privlače posetioce u Britaniju u vansezonskim periodima“", kaže on (Thorne, 2015).

Sredstva koja se izdvajaju za bezbednost velikih sportskih događaja povećavaju se svake godine. Organizatori letnjih olimpijskih igara u Atini 2004. godine uložili su tri do pet puta više novca za bezbednost, sigurnost i prevenciju terorizma u odnosu na izdatke učinjene za prethodne letnje olimpijske igre u Sidneju (Goldblatt, Hu, 2005), a troškovi bezbednosti zimskih olimpijskih igara u Sočiju 2014. iznosili su tri milijarde dolara (Radošević et al., 2016). Zbog povećanih mera obezbeđenja rastu ukupni troškovi same organizacije igara, što na kraju često prevazilazi ostvarenu zaradu i stvara gubitak gradu i državi gde su igre održane.

\section{Bezbednost na manifestacijama}

Događaji i festivali su u suštini deo urbanog života, zastupaju vrlo raznovrsne teme, kao što su tematski festivali, politički događaji, kulturne aktivnosti, sportski događaji, verski sastanci itd. i mogu se održavati na međunarodnom nivou (kao što su: olimpijske igre, FIFA World Cup, World Expo), kao i na nacionalnom nivou (na primer: Oktoberfest u Minhenu, Las Fallas [Festival tepiha i vatre] u Valensiji, Ice Festival u Harbinu [Kina], festival „George Enescu“ u Bukureštu). Takvi događaji postaju sve važniji i za urbani razvoj (koji ima veliki uticaj na sliku grada domaćina), kao i za lokalno stanovništvo (Popescu, Corbos, 2012).

Mnoge su prednosti manifestacionog turizma za destinacije na kojima se on razvija (Getz, 1997):

- privlači turiste, naročito u off-peak sezoni;

- razvija diversifikaciju u turističkoj delatnosti;

- omogućava ravnomerniju raspodelu turizma između različitih destinacija u zemlji;

- kreira nove izvore prihoda za regione;

- povećava poznatost i privlačnost destinacije;

- omogućava da se napravi nova infrastruktura i usluge ili da se razviju trenutna infrastruktura i usluge;

- privlači pažnju i zanimanje medija za destinaciju;

- omogućava destinaciji da izgradi brend tako što će napraviti moćan imidž;

- ohrabruje ljude da posle jedne posete ponovo posete destinaciju.

Manifestacije sa izgrađenim prepoznatljivim imidžom mogu biti snažan motivator za turiste i osnovni nosilac turističke usluge. Međutim, češće se sreće u praksi da su manifestacije samo parcijalni segment ponude turističkog proizvoda i 
da imaju dopunsku ulogu u privlačenju turista. Bez obzira na dominaciju u turističkoj ponudi, manifestacije mogu biti faktor razvoja same destinacije i izgradnje poželjne slike na turističkom tržištu. Isto tako, važno je istaći da čak ni uz najbolje napore turistička destinacija ne može da se razvije ili oživi ako ne nudi visok nivo sigurnosti i bezbednosti potrošačima (Hassan, 2000).

Masovna okupljanja na otvorenom ili u salama, opuštena atmosfera, želja i potreba za novim iskustvom i druženjem sastavni su činioci doživljaja na manifestacijama. Upravo velika koncentracija ljudi na jednome mestu, kao i smanjen nivo opreznosti samih posetilaca na manifestacijama, mogu biti meta terorističkih napada, što je u svetu sve izraženije. Poslednjih nekoliko godina desilo se više ovakvih napada: eksplozija za vreme maratona u Bostonu 2013. (ubijeno troje, a ranjeno 200 ljudi), napad kamionom na božićni sajam u Berlinu 2016. godine (poginulo 12 ljudi, a najmanje 48 povređeno), rafali na dočeku nove 2017. godine u noćnom klubu Reina u Istanbulu (39 mrtvih i 65 povređenih), eksplozija na završetku koncerta američke pevačice Arijane Grande u britanskom gradu Mančesteru u maju 2017. godine (22 osobe su poginule, a 59 je ranjeno) i drugi incidenti.

Takođe, posetioci manifestacija su izloženi delovanju i nekih drugih negativnih pojava: džeparenju, krađama, zarazama, prevarama, ponudi psihoaktivnih supstanci i drugim pretnjama. Svetski ekonomski forum je za potrebe veće bezbednosti putovanja izradio priručnike koji se bave postupcima pre, tokom i posle krize, a zasnovane na najboljim praksama i iskustvima destinacija koje su se susretale sa pojedinim krizama: politički prevrati, terorizam, pandemije, prirodne katastrofe (Tabela 1) (World Economic Forum, 2016).

Tabela 1. Vreme oporavka po kriznoj kategoriji

\begin{tabular}{|l|c|}
\hline Krizna kategorija & $\begin{array}{c}\text { Prosečno vreme } \\
\text { oporavka (meseci) }\end{array}$ \\
\hline politički prevrati & 26,7 \\
\hline terorizam & 13,0 \\
\hline pandemije & 21,3 \\
\hline prirodne katastrofe & 23,8 \\
\hline
\end{tabular}

Izvor: World Travel \& Tourism Council (WTTC), 2017

Istraživanje sprovedeno u Nacionalnoj laboratoriji za turizam i elektronsku trgovinu (NLTeC) na Univerzitetu Temple u Filadelfiji, Pensilvanija, téži da smanji mogućnosti terorističkih napada kroz razvoj onlajn sistema zasnovanog na znanju pod nazivom eSAFE (elektronski sigurnosni festivali i događaji) zasnovan na konceptima upravljanja znanjem. Cilj ovakvog projekta je razvoj veb-rešenjâ za olakšavanje upravljanja znanjem za individualno i organizaciono učenje u kontekstu sigurnosti odvijanja i sigurnosti planiranja festivala i događaja. Ovaj projekat je značajan korak uključivanja organizatora događaja (manifestacija) i pratećih stejkholdera u planiranje bezbednih manifestacija (Goldblatt, $\mathrm{Hu}, 2005$ ). 
Potreba za rešavanjem problema povezanih sa kriminalom i sigurnošću u turističkim gradovima sadržana je u inicijativi Evropskog foruma za urbanu bezbednost (EFUS) na temu „Bezbednost i turizam“ (EFUS, 2015). Ovo je prvi evropski projekat ove vrste koji se bavi turizmom i kriminalom, a posebno se fokusira na gradove u kojima je turizam važna karakteristika ekonomije, a ne na turističke centre uopšte. U projekat je uključeno sedam partnerskih gradova: Alba (Italija), Barselona (Španija), Brašov (Rumunija), Brisel (Belgija), Minhen (Nemačka), Rim (Italija) i Sen-Deni kod Pariza. Projekti koji se odvijaju kroz EFUS omogućavaju različitim gradovima učešće kroz fokusiranje na različite politike i korišćenje raznih metoda istraživanja.

Tako, na primer, Brisel se suočava sa problemima džeparenja i krađe automobila, što je pokrenulo posebnu kampanju nazvanu „Siguran u gradu“, koja je bila namenjena smanjivanju stope ovih pojava. Posebno odeljenje, BRAVO, nadležno za sprečavanje kriminala, uspostavljeno je na opštinskom nivou. I gradski većnici u Minhenu suočeni su sa sličnim problemima, posebno tokom događaja koji koncentrišu veliki broj ljudi: trgovine, sajmovi i festivali. Jedan od ovih događaja, Oktoberfest, privlači milione ljudi koji piju milione litara piva. Kako bi se postigla sigurnost posetilaca, opština je pokrenula razne bezbednosne planove, uključujući poseban program pod nazivom „Bezbedan Oktoberfest za žene i devojke“. Važan deo strategije sigurnosti jesu okrugli stolovi organizovani nakon svake manifestacije sa učešcem zainteresovanih strana kako bi procenili nedostatke manifestacije i dizajnirali planove za poboljšanje budućih organizacija događaja (Mawby et al., 2016).

Navedeni primeri govore u prilog tome da nema apsolutno sigurnih destinacija i da određeni problemi bezbednosti turista uvek preostaju. Kontrolisanje i održavanje bezbednosti turista posebno je otežano u velikim gradovima i na mestima gde se pojavljuje velika koncentracija ljudi. Manifestacije u tom smislu zavređuju punu pažnju lokalnih aktera koji su zaduženi za očuvanje bezbednosti, kao potencijalno visokorizične lokacije u destinaciji. Stoga se u planiranju svake manifestacije, bez obzira na njenu veličinu i mesto održavanja, moraju sprovesti posebna bezbednosna procena i primeniti odgovarajuće mere obezbeđenja.

\section{Bezbednost na manifestacijama u Srbiji}

U Srbiji je manifestacioni turizam Strategijom razvoja turizma Republike Srbije iz 2005. i Strategijom razvoja turizma Republike Srbije iz 2016. godine naglašen kao prosperitetna vrsta turizma, koji značajno utiče na povećanje turističkog prometa i na zaradu koja se ostvaruje od turizma. Od 2005. godine su manifestacije istaknute kao mogući nosioci razvoja turizma pojedinih destinacija, odnosno pojedine su uočene kao potencijalni brend turizma Srbije: EXIT u Novom Sadu, Sabor trubača u Guči, Beer Fest u Beogradu i druge (Strategija razvoja turizma Republike Srbije, 2005). Prema karakteru manifestacije se dele na umetničke, verske, etnografske, političko-istorijske, dečje, zabavne, privredne, naučno-stručne, turističko-propa- 
gandne i sportske. Rang manifestacija može biti međunarodni, nacionalni, regionalni i lokalni. Kao kriterijumi za određivanje ranga izdvajaju se (Bjeljac, 2006, 2010; Bjeljac, Ćurčić, 2010; Bjeljac, Ćurčić, 2011; Bjeljac, Ćurčić, 2016):

- geografsko poreklo i broj posetilaca,

- značaj manifestacije,

- visina sredstava koja se odvajaju shodno rangu organizovanja,

- efekti koji proističu iz manifestacija određeni normama i pravilima postavljenim od strane organizatora,

- geografsko poreklo učesnika i

- sadržaj programa manifestacije.

Istraživanjima je utvrđeno da se u Srbiji godišnje održi oko 2.000 manifestacija različitog karaktera i ranga (Bjeljac, 2010). Od Ulice otvorenog srca 1. januara do dočeka Nove godine 31. decembra samo u Beogradu se održi 237 manifestacija. U Turističkoj organizaciji Beograda ističu da se na svaki dinar uložen u organizaciju manifestacije zaradi od četiri do osam dinara. Manji broj manifestacija se finansira iz budžeta Srbije ili lokalnih samouprava, a najviše njih se sámo izdržava. Najviše prihoda donose inostrani turisti, naročito oni iz Zapadne Evrope, koji u proseku potroše 721 evro. Ostali inostrani gosti potroše po 645, a domaći po 198 evra. Samo pet velikih letnjih manifestacija u Srbiji, kao što su EXIT, Beer fest, Sabor trubača u Guči, Nišvil i Roštiljijada u Leskovcu, dovedu oko dva miliona turista i ostvare prihod od oko 30 miliona EUR. Podaci iz Turističke organizacije Srbije navode da je muzički festival EXIT iz Novog Sada 2016. godine ostvario prihod od 13,94 miliona EUR, a da je poseta stranih turista bila veća za 30\% (Rakočević, 2016).

Značaj razvoja manifestacija i širenje dodatne ponude mogu dovesti do većeg rasta prometa i deviznog priliva od stranih turista. Prema različitim istraživanjima utvrđeno je da $21 \%$ evropskih državljana navode da zabava i festivali ili drugi događaji imaju značajan uticaj na izbor destinacije. Isto tako, $88 \%$ posetilaca festivalâ u Evropi uživa i zadovoljno je hranom i pićem u toku festivala, te dnevno potroše 24 evra samo na piće. Zapravo, veoma je visoka korelacija između festivalâ i koncerata, i potrošnje alkoholnih pića i hrane (Strategija razvoja turizma Republike Srbije, 2016). Srbija je na ovom polju već ranije prepoznata kao destinacija jeftine hrane i pića a njihovog visokog kvaliteta, što kod stranih turista predstavlja bitan motiv za dolazak u Srbiju. Upravo su hrana, piće i muzika „dobitna kombinacija“ koja privlači strane turiste na manifestacije u Srbiju.

Bezbednost na manifestacijama u Srbiji zastupljena je kroz više različitih segmenata i sačinjava deo plana svake manifestacije. Za potrebe regulisanja ponašanja posetilaca i učesnika na manifestacijama i sprečavanja ekscesnih događaja/nasilja doneti su i određeni zakoni i propisi kojima je to regulisano. Najčešće primenjivani zakoni za potrebe nesmetanog održavanja manifestacija jesu: Osnovni krivični zakon, Krivični zakon Republike Srbije, Zakon o zaštiti od požara, Zakon o eksplozivnim materijama, zapaljivim tečnostima i gasovima, Zakon o oružju i municiji, Zakon o javnom redu i miru, Zakon o okupljanjima građana, Zakon o pre- 
kršajima, Zakon o boravku i kretanju stranaca, Zakon o sprečavanju nasilja i nedoličnog ponašanja na sportskim priredbama i drugi.

Većina organizatora za potrebe obezbeđenja manifestacije angažuju privatne agencije koje se primarno bave ovim aktivnostima, poseduju licencu i imaju stručno osposobljene radnike za taj posao. Tako, obezbeđenje javnih skupova, sportskih događaja i manifestacija zahteva angažovanje većeg broja izvršilaca koji su prošli teorijsku i praktičnu obuku za ovaj vid obezbeđenja. Vrsta obuke za radnike obezbeđenja pretežno je iz domena borilačkih veština, protivpožarne zaštite, pružanja prve pomoći, obezbeđenja VIP osoba, vršenja protivdiverzionog pregleda i pregleda naoružanosti stranaka/posetilaca, čuvanje oružja strankama za vreme poseta, ali i kako da reaguju u velikom broju različitih situacija, gde primenjuju ogromno iskustvo stečeno na terenu. Za siguran proces obezbeđenja pre početka manifestacije sačinjava se plan obezbeđenja i dostavlja isti nadležnoj policijskoj upravi zajedno sa prijavom organizatora skupa. Svaki plan obezbeđenja sadrži broj i raspored angažovanih izvršilaca, podatke o licu odgovornom za rukovođenje redarskom službom za vreme trajanja manifestacije i sredstva komunikacije sa njim (Super Glass, 2015). U nekim situacijama mogu da se koriste i životinje òbučene za veću bezbednost. Tako se službeni konji najčešće koriste za obezbeđivanje objekata ili događaja, dok su psi vrlo značajni u poslovima suzbijanja i sprečavanja kriminaliteta (Radio-televizija Vranje, 2016).

Pored redarske službe, odnosno privatne agencije za obezbeđenje, na manifestacijama su prisutne i druge službe koje prate i pružaju pomoć posetiocima i učesnicima. Posebno je važna služba hitne medicinske pomoći koja dežura na mestima gde se odvijaju manifestacije, i to obično na više lokacija kako bi pomoć uvek bila lako dostupna. Prilikom održavanja velikih manifestacija, posebno na otvorenom prostoru i u letnjem delu godine, može biti angažovana i vatrogasna jedinica sa svojim vozilima. Takođe, sve manifestacije su prijavljene MUP-u i odvijaju se uz kontrolu i nadzor policijskih službenika. Samo kompleksan pristup planiranju bezbednosti manifestacija može garantovati visok stepen bezbednosti i sigurnosti za sve učesnike, uz minimizaciju bilo kojeg oblika ekscesnih situacija.

\section{Istraživanje bezbednosti na muzičkom festivalu Green Love u Novom Sadu}

Festival Green Love u Novom Sadu predstavlja muzičku priredbu u vidu tehno-žurki koje se organizuju više puta godišnje u Sportsko-poslovnom centru „Vojvodina“, poznatijem kao SPENS (u velikoj sportskoj sali). Tehno-žurke se od ove godine održavaju i na otvorenom, na Novosadskom sajmu, pored Master centra. Broj posetilaca je veliki, zahvaljujući gostovanju poznatih domaćih i stranih DJ-eva. Na jednoj od žurki zabeleženo je prisustvo 3.000 posetilaca.

$\mathrm{U}$ istraživanju bezbednosti na manifestaciji korišćen je anketni upitnik kojim je sprovedeno anketiranje na festivalu Green Love u Novom Sadu među 
posetiocima. Upitnik je obuhvatio 12 ključnih pitanja vezanih za percipiranu bezbednost posetilaca. Uzorak je obuhvatio 120 ispitanika pretežno mlađih od 29 godina $-96 \%$ (Slika 1). U istraživanju je bilo zastupljeno $52 \%$ ispitanika muškog pola i $48 \%$ ispitanica ženskog pola. Zadatak istraživanja je bio da utvrdi na koji način mladi posetioci percipiraju bezbednost manifestacije i koje su mere ocenili kao dobre, a koje kao slabe.

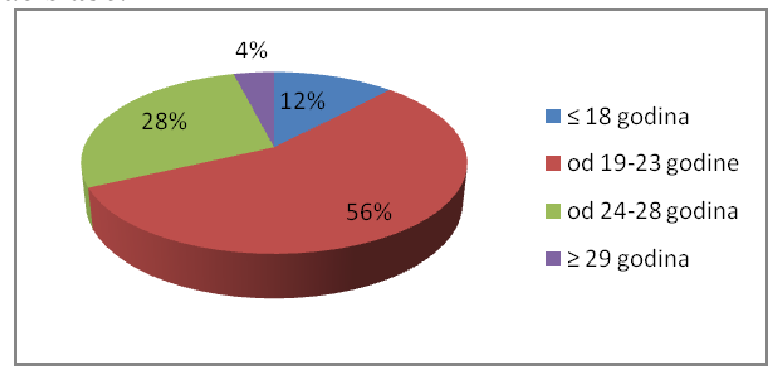

Slika 1. Starosna struktura ispitanika

\subsection{Rezultati istraživanja}

Većina ispitanika tvrdi da se nisu osećali ugroženo na festivalu ni na koji način (72\%), a $28 \%$ je ocenilo da su se u nekim momentima osećali ugroženo. U ovom slučaju je iskazan visok procenat ugroženosti kod posetilaca festivala, što je signal koji upućuje na potrebu provere svih preduzetih bezbedonosnih mera. Osećaj ugroženosti može proisteći iz fizičke ili psihičke ugroženosti pojedinca, i može predstavljati realnu pretnju ili samo lošu ličnu procenu. Bez obzira na oblik ugroženosti i na realnost procene važno je da organizatori ovog festivala nastoje da dalje unapređuju bezbednost i da istraživanjem otkriju koje su to slabe tačke i zašto su procenjene od strane posetilaca kao nebezbedne.

Među anketiranim posetiocima $82 \%$ ispitanika nije prisustvovalo nasilju na festivalu, dok je $18 \%$ prisustvovalo nekom obliku nasilja. Ovaj podatak upućuje da nasilja ima malo, sporadično se javlja i više je posledica promene ponašanja pojedinaca koji su konzumirali alkohol u većoj meri ili su koristili neke od psihoaktivnih supstanci. Sličan rezultat je dobijen i za piće koje se prodaje na samoj manifestaciji: kao potpuno bezbedno ocenjeno je od strane $87 \%$ ispitanika, a da piće nije bezbedno, smatra $13 \%$ anketiranih.

U slučaju potrebe pružanja pomoći nekoj osobi većina ispitanika bi prišla da pomogne $(61 \%)$, dok se $30 \%$ njih dvoumi i možda bi prišli da pruže pomoć u zavisnosti od situacije i problema koji se pojavio (Slika 2). Posetioci festivala bi trebalo u situaciji kada nekom treba pomoć da signalizuju redarima, tj. obezbeđenju, i da sami ne preduzimaju aktivnosti kojima bi možda samo pogoršali stanje ugroženog (pomeranje, podizanje, veštačko disanje, davanje lekova, pića i napitaka i slične radnje). 


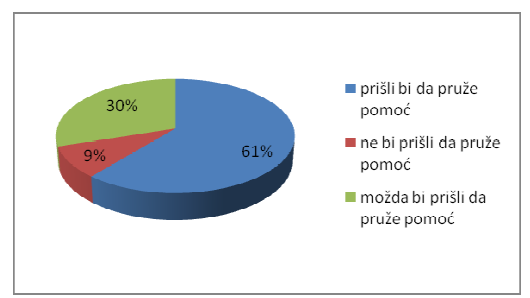

Slika 2. Da li biste pružili pomoć ugroženoj osobi?

Prema oceni 55\% ispitanika na festivalu su lako dostupne psihoaktivne supstance, što je ozbiljan pokazatelj koliko je, i pored mera obezbeđenja, lako uneti razne vrste narkotika, pogotovo sintetičke narkotike (Slika 3). Takođe, 38\% anketiranih je odgovorilo da su im nudili psihoaktivne supstance, što ukazuje na pojavu rasturanja i prodaje narkotika na festivalu i prisustvo dilera na mestima zabave za mlade. Ako se zna da drogu najviše koriste mladi uzrasta između 14 i 25 godina (Dimitrijević, 2008), onda ne čudi situacija da se manifestacije ovog tipa koriste za rasturanje narkotikâ. Takođe, tehno-žurke i provod na njima često se vezuju za upotrebu narkotikâ, što pokazuju i dobijeni odgovori u ovom istraživanju.

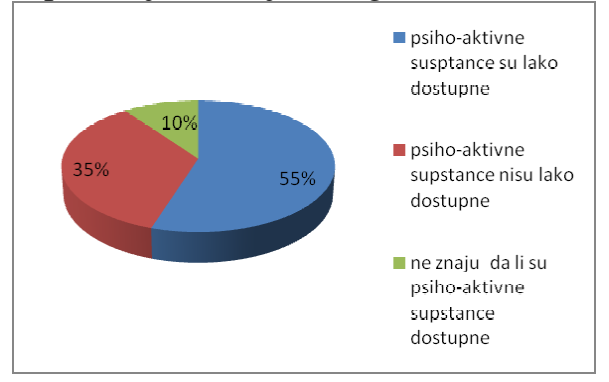

Slika 3. Da li su dostupne psihoaktivne supstance?

Anketirani posetioci festivala Green Love primećuju u visokom procentu $(80 \%)$ da prilikom ulaska u salu nastaju duži zastoji i čekanja usled kontrole posetilaca i smatraju da bi za brži protok ljudi trebalo osposobiti više ulaza (Slika 4). Ujedno, ovi ulazi bi u slučaju potrebe hitnog napuštanja objekta postali izlazi i omogućili brz i nesmetan prolaz ljudi u kraćem vremenskom intervalu, što smanjuje posledice mogućeg stampeda.

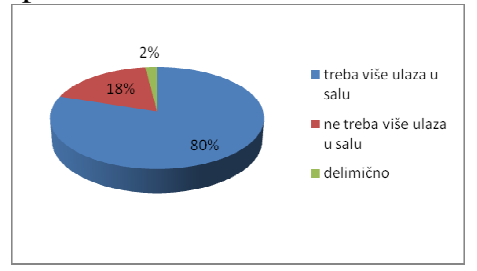

Slika 4. Da li treba više ulaza u salu? 
Učesnici u istraživanju su vrlo jasno zapazili i istakli, kada su u pitanju mere obezbeđenja, da je u samoj sali mali broj redara, te njih $48 \%$ smatra da bi trebalo angažovati više redara (Slika 5). Veće prisustvo redara pružilo bi dodatni osećaj bezbednosti kod posetilaca, s jedne strane, ali bi omogućilo i lakšu kontrolu i koordinaciju u nekoj vanrednoj situaciji, s druge strane.

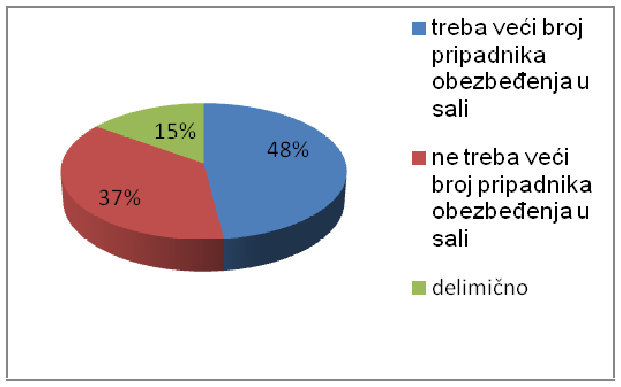

Slika 5. Da li je odgovarajući broj pripadnika obezbeđenja u sali?

Takođe, ispitanici smatraju da je potreban i veći broj policajaca ispred sale (50\%), kao i veći broj medicinskih radnika (72\%) (Slike 6 i 7). Ovakvi podaci ukazuju na visoku svest ispitanika o merama obezbeđenja i uočavanja slabih tačaka u njenoj organizaciji, sa čime se organizator festivala možda ne bi složio, ali bi njihovo poboljšanje svakako doprinelo većem osećaju lične bezbednosti samih posetilaca. Na taj način bi lični doživljaj bezbednosti posetilaca festivala bio kvalitetniji, a imidž festivala bi se brže osnaživao.

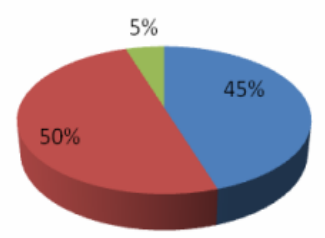

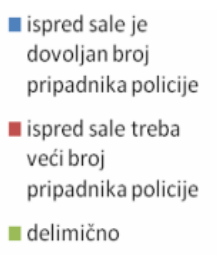

In delimično

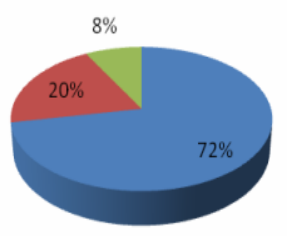

- treba veći broj medicinskih radnika

- dovoljan je broj medicinskih

radnika

= delimično

Slika 6. Da li je odgovarajući broj pripadnika policije?

Slika 7. Da li je odgovarajući broj medicinskih radnika?

Jedan od čestih uzroka tragičnih događaja u klubovima i kafićima u Novom Sadu bili su požari, koji su uvek imali za posledicu i ljudske žrtve. U samo dva velika požara stradalo je 14 mladih ljudi (kafić „Laundž“ 2008. i klub „Kontrast“" 2012. godine), što predstavlja alarmantan podatak za sve one koji drže ugostiteljske objekte ili koji kontrolišu njihov rad. Stoga su ispitanici prepoznali da su požari vrlo ozbiljna pretnja na manifestacijama i istakli da u sali gde se održava festival Green Love treba postaviti više protivpožarnih aparata - 52\% (Slika 8). 


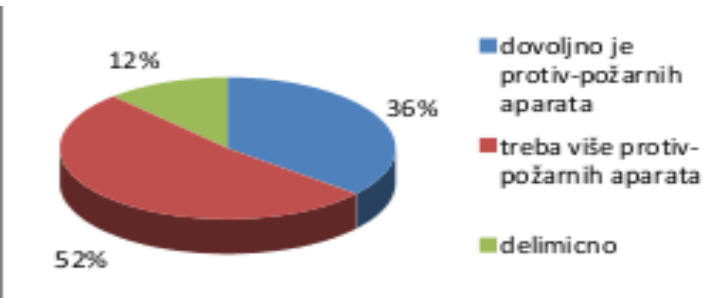

Slika 8. Da li u sali postoji dovoljan broj protivpožarnih aparata?

U zatvorenoj sali se, usled kretanja i igranja velikog broja ljudi, diže prašina u vazduhu, što ometa disanje i stvara osećaj neprijatnosti, pa čak i mogućeg gušenja. Reakcije kod posetilaca javljaju se u vidu iritacije nosa i grla, kao i očiju, što može dovesti do pojava kijanja i kašljanja, curenja iz nosa, peckanja i suzenja očiju, osećaja gušenja. Ovakve reakcije su zastupljene kod alergičnih osoba ili kod lica koja su došla na festival narušenog zdravstvenog stanja, ali ih mogu osetiti i potpuno zdrave osobe. Ispitanici se u velikom procentu slažu da ventilacija ne radi na odgovarajućem nivou (66\%) i da bi načine provetravanja u sali trebalo unaprediti (Slika 9).
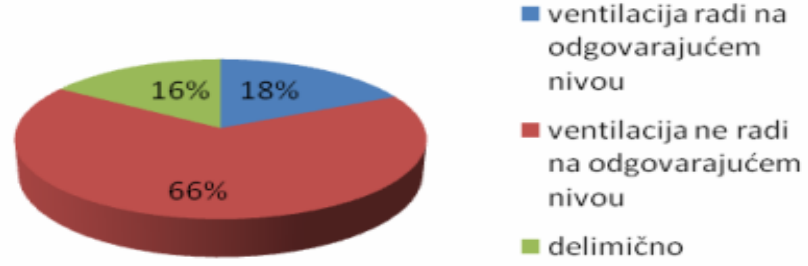

Slika 9. Kakav je rad sistema ventilacije?

\section{Zaključak}

Bezbednost posetilaca i učesnika predstavlja važan faktor u izgradnji imidža kako manifestacije tako i same destinacije. Bezbedna manifestacija izgrađuje viši percipirani lični osećaj zadovoljstva i pruža snažan stimilans za ponavljanje posete manifestaciji, odnosno destinaciji. Ponovljene posete zapravo predstavljaju krajnji cilj i uspeh samog marketinga u smislu razvoja i primene svih njegovih instrumenata, a bezbednost svakako jeste važan element koji marketari često ističu kao bitnu konkurentsku prednost u promociji destinacije.

Festival Green Love je muzička manifestacija za mlade čija bezbednost se dobro planira u smislu pozitivnih zakonskih propisa i procedura. Istraživanje koje je sprovedeno među samim posetiocima festivala pokazalo je da su određeni bez- 
bednosni propusti uočeni i da posetioci vrlo odgovorno razmišljaju o ovoj problematici.

Elementi koji su slabije ocenjeni odnose se na potrebu većeg broja lica koja vrše obezbeđenje u sali, dok bi ispred sale trebalo da bude veći broj medicinskih radnika, kao i veći broj pripadnika policije. Takođe, za bolje tehničko funkcionisanje festivala ispitanici smatraju da bi trebalo obezbediti veći broj ulaza u salu, bolju ventilaciju u toku festivala, kao i veći broj protivpožarnih aparata u sali. Zapažen propust se odnosi i na laku dostupnost psihoaktivnih supstanci na festivalu, što ukazuju na visok nivo izloženosti mladih riziku od droga i povećavanju broja zavisnika.

Rezultati istraživanja mogu pomoći organizatorima manifestacije da unaprede bezbednost kako bi se posetioci osećali što sigurnije. Proaktivan pristup bezbednosti na festivalu omogućiće veće zadovoljstvo posetilaca, bržu izgradnju brenda i dugoročan kontinuitet održavanja same manifestacije. Generalno, rezultati pokazuju da bezbednost turista i posetilaca predstavlja vodeći faktor konkurentnosti kako manifestacije tako i same turističke destinacije.

\section{Literatura}

1. Bhatia, A. K. (2007). The Business of Tourism Concepts and Strategies. Sterling Publishers Private Limited, New Delhi, India.

2. Bjeljac, Ž. (2006). Teorijsko-metodološke osnove manifestacionog turizma. Beograd: Posebna izdanja Geografskog instituta „Jovan Cvijić“, SANU, knjiga 67, str. 154.

3. Bjeljac, Ž. (2010). Turističke manifestacije u Srbiji. Beograd: Posebna izdanja Geografskog instituta „Jovan Cvijić“ SANU, knjiga 7/82, str. 84.

4. Bjeljac, Ž., Ćurčić, N. (2010). Turizmološka valorizacija etnografskih manifestacija u Srbiji. Etnoantropološki problemi n.s. god. 5, sv. 3, str. 227-242.

5. Bjeljac, Ž., Ćurčić, N. (2011). Kategorizacija manifestacija u Srbiji, Hotellink 18/19: 26-34.

6. Bjeljac, Ž., Ćurčić, N. (2016). Kategorizacija i klasifikacija sportskih manifestacija kao deo turističke ponude Srbije. Zbornik radova: I međunarodna konferencija „Sport, rekreacija, zdravlje“, 11-12. jun 2016. godine, Visoka sportska i zdravstena škola, Beograd, str. 25-41.

7. Dimitrijević, B. (2008). Narkomanija kod mladih, dostupno na adresi: http://www. stetoskop.info/Narkomanija-kod-mladih-306-c4-content.htm

8. European Forum for Urban Security. Security and Tourism (2015). Concerted Local Policies; EFUS: Paris, France.

9. FaladeObalade, A. T., Dubey, S. (2014). Managing Tourism as a source of Revenue and Foreign direct investment inflow in a developing Country: The Jordanian Experience. International Journal of Academic Research in Economics and Management Sciences, Vol. 3, No. 3, pp. 16-42. dostupno na adresi: http://hrmars.com/hrmars_papers/Managing_Tourism_as_a_source_of_Revenue_and_Foreign_direct_invest ment_inflow_in_a_developing_Country_The_Jordanian_Experience.pdf

10. Getz, D. (1997). Event management and Event Tourism (1st Ed.). New York: Cognizant Communications Corp. 
11. Getz, D. (2008). Event tourism: Definition, evolution, and research. Tourism Management 29: 403-428.

12. Goldblatt, J., Hu C. (2005). Tourism, Terrorism, and the New World for Event Leaders. e-Review of Tourism Research (eRTR), Vol. 3, No. 6, pp. 139-144.

13. Hassan, S. S. (2000). Determinants of Market Competitiveness in an Environmentally Sustainable Tourism Industry. Journal of Travel Research, Vol. 38, Issue 3, pp. 239-245.

14. Istraživanje bezbednosti na muzičkom festivalu Green Love u Novom Sadu, 2017, 120 anketnih listića.

15. Mawby, R.I.; Tecău, A.S.; Constantin, C.P.; Chiţu, I.B.; Tescaşiu, B. (2016). Addressing the Security Concerns of Locals and Visitors for the Sustainable Development of Tourist Destinations. Sustainability 8, 524.

16. Popescu, R.I., Corboş, R.A. (2012). The Role of Festivals and Cultural Events in the Strategic Development of Cities. Recommendations for Urban Areas in Romania. Informatica Economică 16(4), 19-28.

17. Radio-televizija Vranje (2016) Defileom i pokaznom vežbom završena manifestacija „Dani Vranja“, emitovano 29. 8. 2016. godine, dostupno na adresi: http://www. rtv-vranje.rs/index.php?option=com_k2\&view=item\&id=13464\%3Adefileom-ipokaznom-vezbom-zavrsena-manifestacija-dani-vranja\&Itemid=239

18. Radošević, Z. I., Gavrilović, R. A., Čikiriz, S. N. (2016). Organizaciona i bezbednosna uloga Ministarstva odbrane, Vojske Srbije i Ministarstva unutrašnjih poslova u sportskoj industriji. VOJNO DELO, 7/2016, str. 195-207.

19. Rakočević, J. (2016). Dobra zarada od turističkih manifestacija u Srbiji. Prilog objavljen na RTS-u, 27. 8. 2016. godine, dostupno na adresi: http://www.rts.rs/page/stories/sr/story/13/ekonomija/2432536/dobra-zarada-od-turistickih-manifestacija-u-srbiji.html

20. Strategija razvoja turizma Republike Srbije za period 2005-2015. godina (2005). Horwath Consulting, Zagreb, i Ekonomski fakultet, Beograd.

21. Strategija razvoja turizma Republike Srbije za period od 2016. do 2025. godine (2016). Vlada Republike Srbije, Ministarstvo trgovine, turizma i telekomunikacija, Beograd.

22. Super Glass (2015) Obezbeđenje maniferstacija. Beograd, dostupno na adresi: http://obezbedjenje-sgsecurity.com/usluge/obezbedjenje-manifestacija.html

23. Thorne, R.: Economic impact of sporting events. The Independent. 2015, dostupno na adresi: http://www.independent.co.uk/student/shu/economic-impact-of-sportingevents-10260570.html

24. Trošt, K., Klarić, S., Dropulić Ružić, M. (2012). Events as a Framework for Tourist Destination Branding - Case Studies of Two Cultural Events in Croatia. Turizam, Volume 16, Issue 2, 65-77.

25. UNWTO: Tourism - an economic and social phenomenon. 2016, dostupno na adresi: http://www2.unwto.org/content/why-tourism

26. URS Finance and Economics, Economic Impact of the Rugby World Cup 2003 on the Australian Economy - Post Analysis, prepared for the Department of Industry, Tourism and Resources, June 2004, dostupno na adresama: https://en.wikipedia.org/wiki/Tourism_in_Australia; i http://www.abs.gov.au/AUSSTATS/abs@.nsf/

27. World Economic Forum (2016). Security in Travel - Promoting Seamless and Secure Travel through Cross-Border Data Sharing and Collaboration. Industry Agenda, Switzerland. 
28. World Travel \& Tourism Council (WTTC) (2017). Travel \& Tourism Economic Impact 2017 Serbia, London, UK, dostupno na adresi: https://www.wttc.org/-/media/files/reports/economic-impact-research/countries-2017/serbia2017.pdf

\title{
SAFETY OF TOURISTS AND VISITORS AT THE EVENTS IN URBAN AREAS
}

\begin{abstract}
Summary
Tourism has become a global phenomenon and an important source of income for many countries and regions. In total, Travel \& Tourism generated US\$7.6 trillion (10.2\% of global GDP) and 292 million jobs in 2016, equivalent to 1 in 10 jobs in the global economy. The sector accounted for $6.6 \%$ of total global exports and almost $30 \%$ of total global service exports. In the future we expect its further growth so that in 2027 contributed to the development of the 380 million jobs and the further development of the world economy. The event industry (manifestation) has become one of the main tourist sectors and has made a significant economic contribution to the tourism industry.
\end{abstract}

Attractive elements are important drivers to travel and are present in both the natural and urban environments. Tourist events are an important attractive element in attracting tourists and are an integral part of the tourism product. We offer all the tourist destinations more special events, whose design and execution of conditional strategic reasons, primarily economic. The role of events in the tourist offer of the place is also significant because of their tourist, social and cultural functions, as well as roles in local and regional development.

It is believed that the positive effects of the events are manifested through: further employment of the local population, construction and renovation of facilities, increase revenue host cities, strengthening competitiveness and improving the quality of supply, increase publicity and image building places / events and more.

In Serbia, event tourism, which is the Tourism Development Strategy until 2015, highlighted as prosperous types of tourism, the importance received only at the beginning of the 21 st century. Since then, the events highlighted as potential carriers of tourism development of certain destinations, or individual recognized as a potential tourism brand Serbia (EXIT in Novi Sad, Guca trumpet festival, Beer Fest in Belgrade, etc.). The research showed that in Serbia annually hold about 2000 events of different character and rank. In addition to the popularity of the domestic market, some of the events have the potential and the international market, where by now acquired a certain degree of popularity.

Mass gatherings in the open or in the halls, relaxed atmosphere, the desire and need for a new experience and the friendship are integral factors of experience in events. Just a large concentration of people in one place, as well as a reduced level of vigilance alone visitors to 
events can be a target for terrorist attacks. Also, visitors are exposed to events activities and other negative phenomena: pickpocketing, theft, virus, fraud when changing money, the supply of psychoactive substances and others. The World Economic Forum for the purposes of greater security travel drafted manuals dealing with actions during the crisis and after the crisis, based on best practices and experiences of the destinations that have met certain crises (political upheavals, terrorism, pandemics, disasters in the region). The aim of this study is to show how tourism events have been exposed to phenomena that threaten the safety and security of visitors in general. The study deals with the threatening presence of elements of the tourist events in Serbia and offer some of the solutions that are being undertaken in the world in order to increase security. The authors used a methodology applicable in the social sciences.

In a study on domestic security events used the questionnaire was applied to Green Love Festival in Novi Sad among the visitors of the festival. The sample included 120 respondents mostly under the age of 29 years. The task of the research was to determine how the young visitors perceived safety of the event and what are the measures that have been rated as good, and that as weak. Most respondents felt that they did not feel threatened at the festival in any way $(72 \%)$. Also, $82 \%$ of respondents did not attend the violence at the festival. If necessary, assist a person most would come to help. Drink sold is rated as completely safe. Elements that are less estimated refer to the need for a larger number of persons implementing security in the hall, in front of the hall should be a greater number of medical workers, and a number of police officers. Also, for better technical functioning of the respondents believe that the festival should provide a greater number of entrances to the hall, better ventilation during the festival, as well as the growing number of anti-fire extinguishers in the hall. The research results can help the organizers of the event to improve the safety of visitors in order to feel more secure. A proactive approach to security at the festival will provide greater visitor satisfaction, faster build brand continuity and long-term maintenance of the event. Overall results indicate that the safety of tourists is a leading competitiveness factor to events and tourist destinations themselves.

Keywords: safety of tourists, events, destination competitiveness, urban areas 